\title{
Gamma Ray-Induced Synthesis of Silver Nanoparticles using Bacterial Cellulose as a Multi- Functional Agent and its Application
}

Nasser H. Mohammad

National Centre for Radiation Research and Technology

gamal Mohamed elsherbiny ( $\square$ gamalelsherbiny1970@yahoo.com )

Al-Azhar University https://orcid.org/0000-0003-3968-0536

Ali A. Hammad

National Centre for Radiation Research and Technology

Ahmed A. Askar

Al-Azhar University Faculty of Science

Salwa A. Abou El Nour

National Centre for Radiation Research and Technology

\section{Research Article}

Keywords: Komagataeibacter rhaeticus, bacterial cellulose (BC) AgNPs, and BC/ AgNP composite

Posted Date: June 11th, 2021

DOI: https://doi.org/10.21203/rs.3.rs-522859/v1

License: (9) This work is licensed under a Creative Commons Attribution 4.0 International License. Read Full License 


\section{Abstract}

Antibacterial coatings based on bacterial cellulose (BC) have been widely used in many fields including food packaging and wound dressing. In this study, we aimed to synthesis of colloidal AgNPs and BC/ AgNP composite by using $\mathrm{BC}$ as a reducing and capping agent in one step reaction induced by gammaray. Bacterial strain Komagataeibacter rhaeticus N1 MW322708 was used for biosynthesis BC by inoculation on Hestrin and Schramm medium and incubated statically at $35^{\circ} \mathrm{C}$ for 10 days. BC sheet was formed, harvested, purified, and dried, then used for the synthesis of AgNPs and BC/AgNP by soaked 0.05 $\mathrm{g}$ of dried $\mathrm{BC}$ in $10 \mathrm{ml}$ of $1 \mathrm{mM}$ aqueous $\mathrm{AgNO}_{3}$ solution for $2 \mathrm{~h}$ and then irradiated by gamma-ray under different doses. Color change from yellow to deep brown indicated the synthesis of AgNPs and BC/AgNP. The optical spectra of synthesized AgNPs revealed that the surface plasmon resonance was localized around $420 \mathrm{~nm}$. DLS analysis showed that the mean diameter of AgNPs was $49.5 \mathrm{~nm}$ with a $-19.36-\mathrm{mV}$ value of zeta potential. TEM images revealed the spherical shape of synthesized AgNPs. The results of FESEM, FTIR, and XRD confirmed the formation of $\mathrm{BC} / \mathrm{AgNO}_{3}$ composite. The highly crystalline nature of the $\mathrm{BC}$ membrane and $\mathrm{BC} / \mathrm{AgNP}$ composite was observed in XRD measurements with a crystal size of 5.416 and $5.409 \mathrm{~nm}$, respectively. The antibacterial activity of BC and BC/AgNP against pathogenic bacterial isolated from Pastirma food samples revealed that BC does not show antibacterial activity, while BC/AgNP composite showed antibacterial potency against Staphylococcus aureus, Enterococcus faecalis, Listeria monocytogenes, Proteus mirabilis, and Escherichia coli, with an inhibition zone of $(\mathrm{mm})$ $9 \pm 1,9 \pm 0.57,10 \pm 1.15,8 \pm 0.5$ and $7 \pm 0.28$, respectively. We concluded that this novel method presented in this paper offers a promising route for both AgNPs and BC/AgNP composites synthesis using a green, renewable biopolymer as a multifunctional agent and potential to be applied in the future development of food packing, biomedical instruments, and therapeutics.

\section{Introduction}

Bacterial cellulose $(\mathrm{BC})$ is a versatile biopolymer produced from the metabolic activity of celluloseproducing bacteria such as Komagataeibacter, Agrobacterium, and Rhizobium (Toda et al., 1997; Iguchi et al., 2000; Lin et al., 2013; Rajwade et al., 2015; Petrova et al., 2020). Cellulose synthesized by bacteria has a chemical composition similar to plant cellulose; however, thanks to its structural arrangements but, BC has remarkable physical properties. A study by Lin and the group showed that BC possesses high tensile strength, high crystallinity, high hydrophilicity, and excellent biocompatibility (Lin et al., 2013). BC has very high purity so that making other purification processes (such as delignification), which is very energy-consuming for plant cellulose, is unnecessary (Santoso et al., 2020). BC production gained more attention over the last several decades and its potential uses cover very varied fields including food (Padrao et al., 2016; Azeredo et al., 2019) and medical application (Moniri et al., 2017; Pal et al., 2017 and Jiji et al., 2020). The ability to use BC in diverse application resulting from its stunning properties that include high purity, biodegradability, three-dimensional (3-D) nanofiber, high water holding capacity, good mechanical properties, high crystallinity, and biocompatibility (Shi et al., 2014; Shabanpour et al., 2018; Wang et al., 2019), besides, the availability of incorporating nanostructured materials into BC 3-D network 
structure make it attractive and appropriate for more application (Torres et al., 2019). Nanostructured materials and their applications represent an active area the scientific and traditional levels (Xue et al., 2019). Nanoparticles and nanostructured materials have found their way into different fields such as food (Enescu et al., 2019), medicine (Jiji, 2020), environment (Umar et al., 2016), and so on. It is well known that silver nanoparticle materials have been proven to be the most useful because they showed great antimicrobial performance against a wide range of microorganisms including various bacteria and fungi (Siddiqi et al., 2018 and Wang et al., 2018). AgNPs are extensively used in industrial applications than any other nanomaterial (Vance et al., 2015). However, the aggregation tendency of AgNPs may frustrate their unique properties at the nanoscale. We can prevent aggregation by the incorporation of AgNPs into a nanoporous polymer (Cai, 2009). The 3-D network nanofiber of BC can make it easy and ensure a well- distribution of AgNPs through BC nanofiber and forming BC /AgNP composites (Ifuku et al., 2009; Wu et al., 2014; Torres et al., 2019). Thus BC /AgNP nano-composites aroused great interest among researchers in food packaging (de Moura et al., 2012; Adepu and Khandelwal 2018; Salari et al., 2018 and Azeredo et al., 2019) and wound dressing applications (Manerung et al., 2008; Pal et al., 2017; Tabaii et al., 2018; Horue et al., 2020; Jiji et al., 2020; Wan et al., 2020).

A variety of synthesis methods that including different reducing agent have been investigated to obtain $\mathrm{BC} / \mathrm{AgNP}$ nano- composites which include, sodium borohydride $\left(\mathrm{NaBH}_{4}\right)$ (Maneerung et al., 2008; Pinto et al., 2009; Barud et al., 2011; Wang et al., 2020), sodium tripolyphosphate (TPP) ( Tabaii and Emtiazi, 2018) and triethanolamine (TEA) (Barud et al., 2011). Some of these methods are cost, ecologically unfriendly, and unsafe that need to use toxic chemicals. Thus, the development of green approaches for the synthesis of colloidal $\mathrm{AgNO}_{3}$ and $\mathrm{BC} / \mathrm{AgNP}$ composite is necessary. Recently gamma radiation gains more attention in AgNPs synthesis. Gamma radiation was used to induces the reduction of $\mathrm{Ag}^{+}$into metallic Ag in different aqueous solutions; acetic water solution containing chitosan (Chen et al., 2007), aqueous silk fibroin (SF) solution (Madhukumar et al., 2017), and poly ( $\mathrm{N}$-vinylpyrrolidone) solution (Dhayagude et al., 2018). The main objective of this work is to synthesis of colloidal AgNPs and BC /AgNP composite by green, eco-friendly, free of toxic approach, characterization, and evolution of the antibacterial activity against some pathogenic bacteria.

\section{Materials And Methods}

The most potent bacterial isolate was characterized and identified based on morphological, physiological, biochemical characteristics, 16S rDNA sequence analysis, and recorded in GenBank under accession number (MW322708) strain K. rhaeticus N1 MW322708.

https://www.ncbi.nlm.nih.gov/nuccore/MW322708.

\subsection{Production and purification of bacterial cellulose}

The bacterial strain Komagataeibacter rhaeticus N1 MW322708 strain isolated from Kombucha was used for BC synthesis. K. rhaeticus N1 MW322708 was inoculated into a sterile plastic box that contains $400 \mathrm{ml}$ of Hestrin and Schramm (HS) medium (\% w/v): $2 \%$ glucose, $0.5 \%$ peptone, $0.5 \%$ yeast extract, 
$0.27 \% \mathrm{Na}_{2} \mathrm{HPO}_{4}$, and $0.15 \%$ citric acid (Hestrin \& Schramm, 1954) the medium was modified by adding $1.5 \%$ ethanol to final concentration, the final pH was adjusted to 7, then $K$. rhaeticus $\mathrm{N} 1 \mathrm{MW} 322708$ statically incubated at $35^{\circ} \mathrm{C}$. BC sheet formed in air-liquid phase after 10 days were harvested, treated with $0.1 \mathrm{M} \mathrm{NaOH}$ solution at $85^{\circ} \mathrm{C}$ for $2 \mathrm{~h}$ to remove the bacterial cells, then rinsed several times with deionized water to achieve a neutral $\mathrm{pH}$; finally $\mathrm{BC}$ sheet was dried at $85^{\circ} \mathrm{C}$ for $1 \mathrm{~h}$ and then subjected to autoclave.

\subsection{Synthesis of colloidal AgNPs and BC /AgNP composite under gamma radiation}

Purified $\mathrm{BC}$ sheets $\left(0.05 \mathrm{~g}\right.$, dry weight) were soaked in $10 \mathrm{ml}$ of $1 \mathrm{mM}$ aqueous $\mathrm{AgNO}_{3}$ solution for $2 \mathrm{~h}$ then irradiated by gamma-ray under different doses $(0.2,0.4,0.8,1,5,10,20,40,80$ and100 KGy). BC sheets were taken, rinsed several times with distilled water, and oven-dried at $40^{\circ} \mathrm{C}$. Finally, the deep brown color solution and $\mathrm{BC} / \mathrm{AgNP}$ sheet were stored in dark conditions at $4^{\circ} \mathrm{C}$ for future use.

\subsection{Gamma radiation Source}

Gamma irradiation was applied using a cobalt 60 irradiation source (Gamma cell 4000-A-India), located at the Egyptian Atomic Energy Authority (EAEA), Cairo, Egypt. The irradiation dose rate was $1.0 \mathrm{kGy} / \mathrm{h}$ at the time of the experiment and the irradiation process was carried out at ambient temperature.

\subsection{Characterization of colloidal AgNPs and BC/AgNP composite}

\subsubsection{UV-visible absorption spectra}

UV-visible absorption spectra were recorded on a Cole Parmer spectrophotometer with spectra over a range of $300-800 \mathrm{~nm}$.

\subsubsection{Dynamic Light Scattering (DLS) and Zeta Potential}

DLS measurement was performed on a PSS-NICOMP 380-ZLS particle sizing system (St. Barbara, California, USA). The same instrument was used to obtain the Zeta Potential value. The results were obtained at $25^{\circ} \mathrm{C}$.

\subsubsection{Transmission electron microscopy (TEM)}

The morphology of the obtained AgNPs was obtained with a JEOL JEM-100CX (Japan) transmission electron microscopy

\subsubsection{Field emission scanning electron microscopy (FESEM)}

Morphological characterizations of $\mathrm{BC}$ and $\mathrm{BC} / \mathrm{AgNP}$ composite samples were performed on a Zeiss (Sigma 300 VP; Germany) field emission scanning electron microscopy (FESEM). 


\subsubsection{Fourier transform infrared (FTIR)}

Fourier transforms infrared (FTIR) spectrum was performed on ATI Mattson (Genesis series, Unicom, England). BC/AgNP sheet was scanned at the frequency range of 400 to $4000 \mathrm{~cm}^{-1}$.

\subsubsection{X-ray diffraction analysis (XRD)}

X-ray diffraction spectra of the dried $\mathrm{BC}$ and $\mathrm{BC} / \mathrm{AgNP}$ composite were obtained using the XRD-6000 Shimdazu device (Japan). A standard Theta/2Theta diffractometer (using a copper X-ray source) was used. Scans were performed at 2 degrees per min from the diffraction angle ranged from 4 to $90^{\circ}$. The apparent crystal size (ACS) of BC and BC/AgNP was calculated using Scherrer's equation (Klug and Alexander, 1954), as follows:

$$
\mathrm{ACS}=\frac{\mathrm{K} \lambda}{\beta \cos (\theta)}
$$

Where $k$ is the unknown shape factor and usually considered as $0.9, \lambda$ is the $X$-ray wavelength, $\beta$ is the full width at half maximum in radians and $\theta$ is the diffraction angle

\subsection{Antibacterial activity of $\mathrm{BC}$ and $\mathrm{BC} / \mathrm{AgNP}$ composites}

The antibacterial activity of prepared $\mathrm{BC}, \mathrm{BC} / \mathrm{AgNP}$ composites was determined using the disk diffusion method against Gram-positive (Staphylococcus aureus, Enterococcus faecalis, and Listeria monocytogenes) and Gram-negative (E. coli and Proteus mirabilis) bacteria species were isolated from Pastirma food samples collected from local markets in Cairo, Egypt, and identified by VITEK 2 compact automated system (Biomerieux Inc., Marcy l'Etoile, France). Tested bacteria were cultured into a tube containing $5 \mathrm{ml}$ of Muller Hinton broth (CLSI, 2016) at $37^{\circ} \mathrm{C}$ for $24 \mathrm{~h}$, then $0.1 \mathrm{ml}$ of bacterial suspension with $0.5 \mathrm{McF}$ arland turbidity was swapped on the surface of the Mueller Hinton agar medium, dried discs (6mm in diameter) of BC/AgNP composite and pure $\mathrm{BC}$ were placed on the agar medium along with amoxicillin/clavulanic acid (AMC) $(20 / 10 \mu \mathrm{g} / \mathrm{ml})$, ceftazidime (CAZ) $(30 \mu \mathrm{g} / \mathrm{ml})$ and streptomycin (S) $(10 \mu \mathrm{g} / \mathrm{ml})$ against tested bacteria. The petri-dishes were incubated at $37^{\circ} \mathrm{C}$ for $24 \mathrm{~h}$. The antibacterial activities of the samples against tested organisms were monitored by observing the zone of inhibition formed surrounding the disks. The inhibition zone diameter was measured (Patelet al., 2017; Buszewski et al., 2018).

\section{Results And Discussion}

\section{Bacterial isolates}

The bacterial strain used in this study was isolated from kombucha tea in Egypt and identified by morphological, and biochemical characteristics as well as by 16S rRNA gene sequence analysis and deposit in GenBank under accession number (MW322708) strain K. rhaeticus N1 MW322708. https://www.ncbi.nlm.nih.gov/nuccore/MW322708 


\section{Synthesis of bacterial cellulose}

The $\mathrm{BC}$ produced by $K$. rhatecus in static culture is initially extruded from the pores on the cell surface as microfibres and results in the growth of a dense, white BC pellicle at the air-liquid interface of modified HS medium after 10 days of incubation. Figure (1) shows BC produced by K. rhaeticus N1 MW322708 strain after 10 days using static culture conditions (a), harvesting of $B C(b)$, and $B C$ after purification and drying $(8 \mathrm{~g} / \mathrm{l})$ (c). Komagataeibacter rhaeticus is the most efficient BC producer, as it has the capacity to assimilate several different sugars and yields high levels of cellulose in a liquid culture medium (Rajwadeet al., 2015; Petrova et al., 2020).

\section{Synthesis of AgNPs and BC/AgNP composite under gamma-ray irradiation:}

In this work, gamma-ray was attempted to induce the reduction of $\mathrm{Ag}^{+}$to $\mathrm{Ag}^{\circ}$ by surface $\mathrm{OH}$ groups on $\mathrm{BC}$ surface for synthesis of colloidal AgNPs and BC/AgNP composite, with no chemicals involved in the chemical reaction or no surface modification of $B C$, just pure $B C$ without any surface modification soaked in $\mathrm{AgNO}_{3}$ solution under gamma-ray which promote the reduction process and were used for creating a hydrated electron and primary radicals in many studies (Chen et al., 2007; Park et al., 2012; Van Phu et al., 2014; Madhukumar et al., 2017; Dhayagude et al., 2018). It was found that no apparent color change of the $\mathrm{BC}$ membrane and solution at $(0.2,0.4,0.8,1$, and $5 \mathrm{KGy})$. At $10 \mathrm{kGy}$ visual observations showed that as the reaction started, the color shifted from pale yellow to deep brown for higher doses (20-100 kGy), signifying the reduction of $\mathrm{Ag}^{+}$to $\mathrm{Ag}^{\circ}$ and formation of colloidal AgNPs and $\mathrm{BC} / \mathrm{AgNP}$ composite. Recently, using of $\mathrm{BC}$ as a template in $\mathrm{BC} / \mathrm{AgNP}$ composite synthesis gaining a lot of attention among researchers. The composite synthesis process and the mechanism of reaction in which the metal is reduced and binds onto BC surface have not been studied in much detail in many reports (Kaushik and Moores, 2016). Many researchers showed that it's necessary to make the surface modification of $B C$ by some compounds i.e. TEMPO (2,2,6,6-tetramethylpiperidine-1-oxyl radical), that oxidize BC and introducing surface-active carboxyl groups for BC /AgNP composite synthesis (Lal and Mhaske 2018; Elayaraja et al., 2020). Recently, Musino et al., (2021) showed that the hydroxyl groups on the surface of $\mathrm{BC}$ act as nucleation points for AgNPs through ion-dipole interaction, and $\mathrm{OH}$ groups represent the effective nucleation point for AgNPs synthesis on a BC solid surface. As far as we know it's the first study for the synthesis of colloidal AgNPs and BC/AgNP composite using only $\mathrm{BC}$ as a reducing and stabilizing agent under gamma radiation.

\section{UV-visible spectrum}

Figure (2) showed UV-visible spectrum of AgNPs synthesized by BC under different doses of gamma-ray. The reduction of $\mathrm{Ag}^{+}$to $\mathrm{Ag}^{\circ}$ by $\mathrm{OH}$ groups on $\mathrm{BC}$ surface under gamma-ray was preliminarily identified by observing the change in color of the reaction medium from clear to yellowish-brown. The change in color to the pale yellow of the reaction mixture started at a dose of $10 \mathrm{KGy}$ and gradually turned to deep brownat higher doses $(20,40,80$, and $100 \mathrm{KGy})$. It is well known that AgNPs show a yellowish-brown color in water or aqueous solution; these colors arise due to the excitation of surface plasmon vibrations in the 
metal nanoparticles (Shankar et al., 2004). This color change was associated with the development of a strong absorption band at 420 in the UV-vis. spectrum. This UV-Visible absorption peak at around $420 \mathrm{~nm}$ was attributed to the surface plasmon resonance (SPR) absorption peak of AgNPs, which confirmed the AgNPs formation with small size and narrow size distribution. Appeared peak around $420 \mathrm{~nm}$ was previously reported as a spherical or quasi-spherical Ag NPs SPR band (Sivasankar et al., 2018; Tabaiiet al., 2018).

\section{DLS analysis}

To accurately measure the mean diameter of synthesized AgNPs DLS analysis was used. The results of the DLS analysis (Fig. 2) showed that the mean diameter of AgNPs was $49.5 \mathrm{~nm}$. The size distribution of colloidal AgNPs illustrated by details in a table (1)

\section{Zeta potential analysis}

Zeta potential measures the electric charge on the surface of nanoparticles. Zeta potential value delivers information about the stability of nanoparticles. When nanoparticles in suspension have a large negative zeta potential value, nanoparticles will tend to repel with each other, thus there will be no tendency of the nanoparticles to agglomerate together. In contrast, in the case of low zeta potential values, no force to prevent the nanoparticles from coming together, thus nanoparticles tend to agglomerate (Roy et al., 2013). The value of the zeta potential of colloidal AgNPs was - $19.36 \mathrm{mV}$ (Fig. 4). Obtained results from zeta potential proved that synthesized AgNPs were poly-dispersed, due to the high negative zeta potential value. The electrostatic repulsive force between nanoparticles results in the prevention of flocculation of nanoparticles and has an important role in nanoparticles' long-term stability in the solution (Kotakadi et al., 2016).

\section{TEM examination}

TEM examination of synthesized AgNPs was used to obtain information about the morphology and size of metal nanostructures. The obtained result revealed that the shape of obtained AgNPs was spherical (Fig. 5).

\section{FE-SEM examination}

FE-SEM images of BC and BC /AgNP composite shows three-dimensional structures of BC nanofibers. After the $\mathrm{BC}$ sheet was soaked in $\mathrm{AgNO}_{3}$ for $2 \mathrm{~h}$ and then irradiated, silver ions reduced by $\mathrm{OH}$ surface groups of BC to AgNPs (white dots) which appeared to adhere to the surface of BC fibers (Fig. 6).

FTIR spectrum was performed to detect the interaction between BC and Ag-NPs. Figures (7) and table (2) show the FTIR spectra of $\mathrm{BC}$ and $\mathrm{BC} / \mathrm{Ag}$ nanocomposites. For $\mathrm{BC}$ (a) characteristic bands of cellulose that appeared at the $3200-3400 \mathrm{~cm}^{-1}$ region are assigned to the $\mathrm{OH}$ stretching vibration of the hydroxyl groups present in the BC nanofiber (Zhu et al., 2014; Cacicedo et al., 2020). Peaks at $3000-2800 \mathrm{~cm}^{-1}$ were assigned to the stretching vibrations of the $\mathrm{CH}_{2}$ and $\mathrm{CH}_{2}-\mathrm{OH}$ groups (Liet al., 2011; Cacicedo et al., 
2020). The band at $1640 \mathrm{~cm}^{-1}$ can be assigned to $C=0$ (Wang et al., 2017). The band at $1426.38 \mathrm{~cm}^{-1}$ is assigned to the stretching vibrations of $\mathrm{CH}_{2}$ or $\mathrm{OH}$ in-plane bending (Barud et al., 2011). The peak at 1321.94 to 1369.67 can be assigned to O-H in-plane bending (Osorioet al., 2019). The band at 1022.36 $\mathrm{cm}^{-1}$ for the $\mathrm{C}-\mathrm{O}-\mathrm{C}$ and $\mathrm{C}-\mathrm{O}-\mathrm{H}$ stretching vibrations of the sugar ring (Huang et al., 2015). The absorption at $1158.31 \mathrm{~cm}^{-1}$ is coming from the $\mathrm{C}-\mathrm{O}-\mathrm{C}$ stretching vibration of the pure cellulose. A group of absorption peaks at the wavenumber region of $1200-900 \mathrm{~cm}^{-1}$ arise due to the $\mathrm{C}-\mathrm{O}$ and $\mathrm{C}-\mathrm{C}$ stretching vibrations of the cellulose network (Cui et al., 2014). The FTIR spectrum of BC/AgNP composite (b) contained all the characteristic peaks of $\mathrm{BC}$ along with an additional new band for AgNPs at $1545.5 \mathrm{~cm}^{-1}$ in the $\mathrm{BC} / \mathrm{AgNP}$ composite resulting from the hydrogen bonding interaction between $\mathrm{BC}$ and AgNPs (Wang et al., 2017; Wan et al., 2020).

\section{XRD analysis}

XRD patterns provide information about the crystalline structure of $\mathrm{BC}$ and $\mathrm{BC} / \mathrm{AgNP}$ composite. Figure (8) showed three diffraction peaks at about $14.32^{\circ}, 16.82^{\circ}, 22.57^{\circ}$, and $14.66^{\circ}, 16.56^{\circ}, 22.86^{\circ}$ for BC and BC/AgNP composite respectively, the peaks corresponded to (110), (110), and (200) crystal planes of cellulose (French, 2014and Volova et al., 2018). In many studies, the XRD of pure BC membrane showed three characteristic peaks at $14.60^{\circ}, 16.82^{\circ}$, and $22.78^{\circ}$ (Yan et al., 2008; Ul-Islam et al., 2013; Wu et al., 2014). The XRD graph of BC/AgNP composite exhibited newly three peaks $27.4^{\circ}, 32.4^{\circ}$, and $46.5^{\circ}$ attributed to the diffractions from the planes of Ag. Mageswariet al ., (2015) reported diffraction peaks of $46^{\circ}, 54^{\circ}$, and $68^{\circ}$, that attributed to 211,220 , and 222 lattice planes of the face-centered cubic crystal structure of silver, while diffraction peak at $26^{\circ}$ and $32^{\circ}$ was indexed to 110 and 111 , planes of silver oxide. In many studies, the face-centered cubic crystal structure of crystalline Ag showed diffraction peaks at around $38^{\circ}, 46^{\circ}$, and $64^{\circ}$ that was attributed to the planes of 111,200 and 220 , respectively (Prakash et al., 2013; Jyoti et al., 2016and Anjum and Abbasi, 2016). The peak at about $27^{\circ}$ and $32^{\circ}$ was also reported for the diffractions from the planes of silver (Kumar et al., 2012and Rose et al., 2019).

The apparent crystal size ( $\mathrm{nm}$ ) of $\mathrm{BC}$ and BC/AgNP composite are reported in Table (3). According to the Scherrer equation, the peak that was used for calculating the crystalline size of $\mathrm{BC}$ and $\mathrm{BC} / \mathrm{AgNP}$ was $22.57^{\circ}$ and $22.86^{\circ}$ respectively. The average size of the $B C$ membrane is determined to be $5.416 \mathrm{~nm}$ and $5.4091 \mathrm{~nm}$ for BC/AgNP composite.

Table (4) show the antibacterial activity of BC/AgNP composite, purified BC, AMC, CAZ, and S against Gram-positive (Staphylococcus aureus, Enterococcus faecalis, and Listeria monocytogenes) and Gramnegative (proteus mirabilis and E. coli) bacteria. Purified BC and amoxicillin/clavulanic acid did not show antibacterial activity against any tested bacteria. Listeria monocytogenes, Proteus mirabilis, and E. coli were resistant to ceftazidime. BC/AgNP composite and streptomycin showed antibacterial potency against both Gram-positive and Gram-negative bacteria. It was observed that Enterococcus faecalis, Staphylococcus aureus, and Listeria monocytogenes were more sensitive and gave higher inhibition zone for BC/ AgNP composite while Gram-negative E. coli and Proteus mirabilis were more resistant. Many studies reported that AgNPs have shown higher antimicrobial potency in Gram-positive than Gram- 
negative bacteria (Mandal et al., 2016; El-Sherbinyet al., 2020, Jiji et al., 2020). the antibacterial activity of AgNPs depends on many factors including size, charge, the concentration of AgNPs (Van Phu et al., 2014, Jiji et al., 2020), and also the stabilizer used (Phu et al., 2014). Various mechanisms have been proposed for the antibacterial action of AgNPs, the most common one can be that free silver ions uptake may preventing DNA replication or may cause direct damage to the bacterial cell wall by forming pits in the cell wall that lead to an increase in permeability of cell wall and final cell death (Jones and Hoek, 2010; Bapat et al., 2018).

\section{Conclusion}

In this work, a facile green method for the preparation of colloidal AgNPs and BC/ AgNP composite under the induction effect of gamma radiation. $\mathrm{BC}$ soaked in $\mathrm{AgNO}_{3}$ was used as a reducing and capping agent. There is no need for using a chemical reducing agent or a supplementary catalyst in this way. The prepared composite exhibit antibacterial activity against Gram-positive and Gram-negative bacteria. Therefore, the $\mathrm{BC} / \mathrm{AgNP}$ composite has the great potential to be applied in the future development of biomedical instruments, food packaging, and therapeutics such as wound dressing.

\section{Declarations}

\section{Conflict of interest}

The authors declare that they have no conflict of interest.

\section{Funding}

$\mathrm{N} / \mathrm{A}$

Human Participants and/or Animals

N/A

Informed consent

$\mathrm{N} / \mathrm{A}$

\section{References}

1. Adepu S., Khandelwal M. (2018): Broad-spectrum antimicrobial activity of bacterial cellulose silver nanocomposites with sustained release. Journal of Materials Science, 53 (3):1596-1609.

2. Anjum S., Abbasi B.H. (2016): Biomimetic synthesis of antimicrobial silver nanoparticles using in vitro-propagated plantlets of a medicinally important endangered species. Phlomis bracteosa. International journal of nanomedicine, 11:1663. 
3. Azeredo H., Barud H., Farinas C.S., Vasconcellos V.M., Claro A.M. (2019): Bacterial cellulose as a raw material for food and food packaging applications. Frontiers in Sustainable Food Systems, 3:7.

4. Bapat R.A., Chaubal T.V., Joshi C.P., Bapat P.R., Choudhury H., Pandey M., Gorain B., Kesharwani P. (2018): An overview of application of silver nanoparticles for biomaterials in dentistry. Materials Science and Engineering: C, 91:881-898.

5. Barud H. S., Regiani T., Marques R.F., Lustri W.R., Messaddeq Y., Ribeiro S.J. (2011): Antimicrobial bacterial cellulose-silver nanoparticles composite membranes. Journal of Nanomaterials, 2011

6. Buszewski B., Viorica R.P, Paweł P., Katarzyna R., Malgorzata S.M., PatrycjaG, et al. Antimicrobial activity of biosilver nanoparticles produced by a novel Streptacidiphilus durhamensis strain. $J$ Microbiol Immunol Infect 2018;51:45-54

7. Cacicedo M. L., Pacheco G., Islan G. A., Alvarez V.A., Barud H.S, Castro G.R. (2020): Chitosan-bacterial cellulose patch of ciprofloxacin for wound dressing: preparation and characterization studies. International journal of biological macromolecules, 147:1136-1145.

8. Cai J., Kimura S., Wada M., Kuga S. (2009): Nanoporous cellulose as metal nanoparticles support. Biomacromolecules, 10 (1):87-94.

9. Chen P., Song L., Liu Y., Fang Y (2007): Synthesis of silver nanoparticles by y-ray irradiation in acetic water solution containing chitosan. Radiation Physics and Chemistry, 76 (7):1165-1168.

10. CLSI. Performance Standards for Antimicrobial Susceptibility Testing, Supplement M100S. 26th ed. Wayne, PA, USA: Clinical and Laboratory Standards Institute; 2016

11. Cui Q., Zheng Y., Lin Q., Song W., Qiao K., Liu S. (2014): Selective oxidation of bacterial cellulose by $\mathrm{NO}_{2}-\mathrm{HNO}_{3}$. RSC Advances, 4 (4):1630-1639.

12. De Moura M. R., Mattoso L.H., Zucolotto V. (2012): Development of cellulose-based bactericidal nanocomposites containing silver nanoparticles and their use as active food packaging. Journal of Food Engineering, 109 (3):520-524.

13. Dhayagude A.C., Das A., Joshi S.S., Kapoor S. (2018): YRadiation-induced synthesis of silver nanoparticles in aqueous poly ( $\mathrm{N}$-vinylpyrrolidone) solution. Colloids and Surfaces $\mathrm{A}$ : Physicochemical and Engineering Aspects, 556:148-156.

14. Elayaraja S., Liu G., Zagorsek K., Mabrok M., Ji M., Ye Z., Zhu S., Rodkhum C. (2020): TEMPOoxidized biodegradable bacterial cellulose (BBC) membrane coated with biologically-synthesized silver nanoparticles (AgNPs) as a potential antimicrobial agent in aquaculture (In-vitro). Aquaculture, 530:735746.

15. El-Sherbiny G.M., Lila M. K., Shetaia Y.M., Elswify M.M., Mohamed S. S. (2020) Antimicrobial activity of biosynthesized silver nanoparticles against multidrug-resistant microbes isolated from cancer patients with bacteremia and candidemia. Indian J Med Microbiol 38(3) 371-378

16. Enescu D., Cerqueira M.A., Fucinos P., Pastrana L.M. (2019): Recent advances and challenges on applications of nanotechnology in food packaging. A literature review. Food and Chemical Toxicology, 134:110814. 
17. French A.D. (2014): Idealized powder diffraction patterns for cellulose polymorphs. Cellulose, 21 (2):885-896.

18. Hestrin S., Schramm M. (1954): Synthesis of cellulose by Acetobacter xylinum. 2. Preparation of freeze-dried cells capable of polymerizing glucose to cellulose. Biochemical Journal, 58 (2):345.

19. Horue M., Cacicedo M.L., Fernandez M.A., Rodenak-Kladniew B., Sánchez R.M.T., Castro G.R. (2020): Antimicrobial activities of bacterial cellulose-Silver montmorillonite nanocomposites for wound healing. Materials Science and Engineering: C, 116:111152.

20. Huang C., Yang X.Y., Xiong L., Guo H.J., Luo J., Wang B., Zhang H.R., Lin, X.Q. and Chen X.D. (2015): Evaluating the possibility of using acetone-butanol-ethanol (ABE) fermentation wastewater for bacterial cellulose production by Gluconacetobacter xylinus. Letters in applied microbiology, 60 (5):491-496.

21. Ifuku S., Tsuji M., Morimoto M., Saimoto H., Yano, H. (2009): Synthesis of silver nanoparticles templated by TEMPO-mediated oxidized bacterial cellulose nanofibers. Biomacromolecules, 10 (9):2714-2717.

22. Iguchi M, Yamanaka S, Budhiono A (2000) Bacterial cellulose-a masterpiece of nature's arts. J Mater Sci 35:261-270

23. Jiji S., Udhayakumar S., Maharajan K., Rose C., Muralidharan C, Kadirvelu K. (2020): Bacterial cellulose matrix within situ impregnation of silver nanoparticles via catecholic redox chemistry for third-degree burn wound healing. Carbohydrate Polymers, 245:116573.

24. Jones C, Hoek E.M. (2010): A review of the antibacterial effects of silver nanomaterials and potential implications for human health and the environment. Journal of Nanoparticle Research, 12 (5):15311551.

25. Jyoti K., Baunthiyal M., Singh A. (2016): Characterization of silver nanoparticles synthesized using Urtica dioica Linn. leaves and their synergistic effects with antibiotics. Journal of Radiation Research and Applied Sciences, 9 (3):217-227.

26. Kaushik M., Moores A. (2016): Nanocelluloses as versatile supports for metal nanoparticles and their applications in catalysis. Green Chemistry, 18 (3):622-637.

27. Klug H.P., Alexander L.E. (1954): X-Ray Procedures. Wiley/ Interscience, New York, pp. 491-538.

28. Kotakadi V.S., Gaddam S.A., Venkata S.K., Sarma P. Gopal, D.S. (2016): Biofabrication and spectral characterization of silver nanoparticles and their cytotoxic studies on human CD34+ ve stem cells. Biotech, 6 (2):1-11.

29. Kumar R., Roopan S.M., Prabhakarn A., Khanna V.G., Chakroborty S. (2012): Agricultural waste Annona squamosa peel extract: biosynthesis of silver nanoparticles. Spectrochimica Acta Part A: Molecular and Biomolecular Spectroscopy, 90:173-176.

30. Lal S.S., Mhaske S.T. (2018): AgBr and AgCl nanoparticle doped TEMPO-oxidized microfiber cellulose as a starting material for antimicrobial filter. Carbohydrate Polymers, 191:266-279.

31. Lin S. P, Calva L.L, Catchmark J.M, Liu J.R, Demirci A, Cheng K. C. (2013) Biosynthesis, production and applications of bacterial cellulose. Cellulose 20:2191-2219 
32. Li Q., Renneckar S. (2011): Supramolecular structure characterization of molecularly thin cellulose I nanoparticles. Biomacromolecules, 12 (3):650-659.

33. Li Z., Wang L., Chen S., Feng C., Chen S., Yin N., Yang J., Wang H., Xu Y. (2015): Facilely green synthesis of silver nanoparticles into bacterial cellulose. Cellulose, 22 (1):373-383.

34. Madhukumar R.; Byrappa K., Wang Y., Sangappa Y. (2017): Effect of gamma irradiation on synthesis and characterization of bio-nanocomposite SF/Ag nanoparticles. Radiation Effects and Defects in Solids, 172 (11-12):915-921.

35. Mageswari A., Subramanian P., Ravindran V., Yesodharan S., Bagavan A., Rahuman A.A., Karthikeyan S., Gothandam K.M. (2015): Synthesis and larvicidal activity of low-temperature stable silver nanoparticles from psychrotolerant Pseudomonas mandelii. Environmental Science and Pollution Research, 22 (7):5383-5394.

36. Mandal D., Dash S. K., Das B., Chattopadhyay S., Ghosh T., Das D., Roy S. (2016): Bio-fabricated silver nanoparticles preferentially target Gram-positive depending on cell surface charge. Biomedicine \& Pharmacotherapy, 83:548-558.

37. Maneerung T., Tokura S., Rujiravanit R. (2008): Impregnation of silver nanoparticles into bacterial cellulose for antimicrobial wound dressing. Carbohydrate Polymers, 72 (1):43-51.

38. Moniri M., Boroumand M. A., Azizi S., Abdul Rahim R., Bin Ariff A., Zuhainis S. W., Navaderi M., Mohamad R. (2017): Production and status of bacterial cellulose in biomedical engineering. Nanomaterials, 7 (9):257.

39. Musino D., Rivard C., Landrot G., Novales B., Rabilloud T., Capron I. (2021): Hydroxyl groups on cellulose nanocrystal surfaces form nucleation points for silver nanoparticles of varying shapes and sizes. Journal of Colloid and Interface Science, 584:360-371.

40. Osorio M., Ortiz I., Gañán P., Naranjo T., Zuluaga R., van Kooten T., Castro C. (2019): Novel surface modification of three-dimensional bacterial nanocellulose with cell-derived adhesion proteins for soft tissue engineering. Materials Science and Engineering: C, 100:697-705.

41. Padrao J., Gonçalves S., Silva J.P., Sencadas V., Lanceros-Méndez S., Pinheiro A. C., Vicente A. A., Rodrigues L.R., Dourado F. (2016): Bacterial cellulose-lactoferrin as an antimicrobial edible packaging. Food hydrocolloids, 58:126-140.

42. Pal S., Nisi R., Stoppa M., Licciulli A. (2017): Silver-functionalized bacterial cellulose as antibacterial membrane for wound-healing applications. ACS Omega, 2 (7):3632-3639.

43. Park J. S, Kuang J., Lim Y. M., Gwon H. J., Nho Y. C. (2012): Characterization of silver nanoparticle in the carboxymethyl cellulose hydrogel prepared by gamma-ray irradiation. Journal of nanoscience and nanotechnology, 12 (1):743-747.

44. Patel, J. et al. M100 Performance Standards for Antimicrobial Susceptibility Testing 240 (Clinical and Laboratory Standards Institute, Wayne, 2017).

45. Petrova V. A., Khripunov A. K., Golovkin A. S., Mishanin A. I., Gofman I. V., Romanov D. P., et al., (2020) Bacterial Cellulose (Komagataeibacter rhaeticus) Biocomposites and Their Cytocompatibility Materials 2020, 13, 4558; doi:10.3390/ma13204558 
46. Pinto R. J., Marques P. A., Neto C. P., Trindade T., Daina S., Sadocco P. (2009): Antibacterial activity of nanocomposites of silver and bacterial or vegetable cellulosic fibers. Acta Biomaterialia, 5 (6):22792289.

47. Prakash P., Gnanaprakasam P., Emmanuel R., Arokiyaraj, S., Saravanan M. (2013): Green synthesis of silver nanoparticles from leaf extract of Mimusops elengi, Linn. for enhanced antibacterial activity against multidrug-resistant clinical isolates. Colloids and surfaces B: Biointerfaces, 108:255-259.

48. Rajwade, J.M.; Paknikar, K.M.; Kumbhar, J.V. Applications of bacterial cellulose and its composites in biomedicine. Appl. Microbiol. Biotechnol. 2015, 99, 2491-2511.

49. Rose G.K., Soni R., Rishi P., Soni S.K. (2019): Optimization of the biological synthesis of silver nanoparticles using Penicillium oxalicum GRS-1 and their antimicrobial effects against common food-borne pathogens. Green Processing and Synthesis, 8 (1):144-156.

50. Roy S., Mukherjee T., Chakraborty S., Das T.K. (2013): Biosynthesis, characterization \& antifungal activity of Silver nanoparticles synthesized by the fungus aspergillus Foetidus mtcc8876. Digest Journal of Nanomaterials and Biostructures, 8 (1):197-205.

51. Santoso, S.P., Chou, CC., Lin, SP. et al. Enhanced production of bacterial cellulose by Komactobacter intermedius using statistical modeling. Cellulose27, 2497-2509

(2020). https://doi.org/10.1007/s10570-019-02961-57.

52. Salari M., Khiabani M.S., Mokarram R.R., Ghanbarzadeh B., Kafil H.S. (2018): Development and evaluation of chitosan-based active nanocomposite films containing bacterial cellulose nanocrystals and silver nanoparticles. Food hydrocolloids, 84:414-423.

53. Shabanpour B., Kazemi M., Ojagh S.M., Pourashouri P. (2018): Bacterial cellulose nanofibers as reinforce in edible fish myofibrillar protein nanocomposite films. International journal of biological macromolecules, 117:742-751.

54. Shankar S.S., Rai A., Ahmad A., Sastry M. (2004): Rapid synthesis of Au, Ag, and bimetallic Au coreAg shell nanoparticles using Neem (Azadirachta indica) leaf broth. Journal of Colloid and Interface Science, 275 (2):496-502.

55. Shi Z., Zhang Y., Phillips G.0., Yang G. (2014): Utilization of bacterial cellulose in food. Food hydrocolloids, 35:539-545.

56. Siddiqi K.S., Husen A., Rao R.A. (2018): A review on biosynthesis of silver nanoparticles and their biocidal properties. Journal of nanobiotechnology, 16 (1):1-28.

57. Sivasankar P., Seedevi P., Poongodi S., Sivakumar M., Murugan T., Sivakumar L., Sivakumar K., Balasubramanian T. (2018): Characterization, antimicrobial and antioxidant property of exopolysaccharide mediated silver nanoparticles synthesized by Streptomyces violaceus MM72. Carbohydrate Polymers, 181:752-759.

58. Tabaii M.J., Emtiazi G. (2018): Transparent nontoxic antibacterial wound dressing based on silver nanoparticle/bacterial cellulose nanocomposite synthesized in the presence of tripolyphosphate. Journal of Drug Delivery Science and Technology, 44:244-253. 
59. Toda K, Asakura T, Fukaya M, Entani E, Kawamura Y (1997) Cellulose production by acetic acidresistant Acetobacter xylinum. J Biosci Bioeng 84:228-231

60. Torres F., Arroyo J., Troncoso 0. (2019): Bacterial cellulose nanocomposites: An all-nano type of material. Materials Science and Engineering: C, 98:1277-1293.

61. Ul-Islam M., Ha J.H., Khan T., Park, J.K. (2013): Effects of glucuronic acid oligomers on the production, structure, and properties of bacterial cellulose. Carbohydrate Polymers, 92 (1):360-366.

62. Umar K., Aris A., Ahmad H., Parveen T., Jaafar J., Majid Z. A., Reddy A.V.B., Talib J. (2016): Synthesis of visible light active doped $\mathrm{TiO}_{2}$ for the degradation of organic pollutants-methylene blue and glyphosate. Journal of Analytical Science and Technology, 7 (1):1-8.

63. Van Phu D., Duy N.N., Lan N. T. K., Du B.D., Hien N.Q. (2014): Study on antibacterial activity of silver nanoparticles synthesized by gamma irradiation method using different stabilizers. Nanoscale research letters, 9 (1):1-5.

64. Vance M.E., Kuiken T., Vejerano E.P., McGinnis S.P., Hochella J. M.F., Rejeski D., Hull M.S. (2015): Nanotechnology in the real world: Redeveloping the nanomaterial consumer products inventory. Beilstein journal of nanotechnology, 6 (1):1769-1780.

65. Volova T.G., Shumilova A.A., Shidlovskiy I.P., Nikolaeva E.D., Sukovatiy A.G., Vasiliev A.D., Shishatskaya E.I. (2018): Antibacterial properties of films of cellulose composites with silver nanoparticles and antibiotics. Polymer Testing, 65:54-68.

66. Wan Y., Yang S., Wang J., Gan D., Gama M., Yang Z., Zhu Y., Yao F., Luo H. (2020): Scalable synthesis of robust and stretchable composite wound dressings by dispersing silver nanowires in continuous bacterial cellulose. Composites Part B: Engineering, 199:108259.

67. Wan Y., Yang S., Wang J., Gan D., Gama M., Yang Z., Zhu Y., Yao F., Luo H. (2020): Scalable synthesis of robust and stretchable composite wound dressings by dispersing silver nanowires in continuous bacterial cellulose. Composites Part B: Engineering, 199:108259.

68. Wang J., Tavakoli J., Tang Y. (2019): Bacterial cellulose production, properties, and applications with different culture methods-A review. Carbohydrate Polymers, 219:63-76.

69. Wang T., Ma B., Jin A., Li X., Zhang X., Wang W., Cai Y. (2018): Facile loading of Ag nanoparticles onto magnetic microsphere by the aid of tannic acid-metal polymer layer to synthesize magnetic disinfectant with high antibacterial activity. Journal of hazardous materials, 342:392-400.

70. Wang Y., Gu F. Q., Ni L. J., Liang K., Marcus K., Liu S. I., Yang F., Chen J., Feng, Z. S. (2017): Easily fabricated and lightweight PPy/PDA/AgNW composites for excellent electromagnetic interference shielding. Nanoscale, 9 (46):18318-18325.

71. Wu J., Zheng Y., Song W., Luan J., Wen X., Wu Z., Chen X., Wang Q., Guo S. (2014): In situ synthesis of silver-nanoparticles/bacterial cellulose composites for slow-released antimicrobial wound dressing. Carbohydrate Polymers, 102:762-771.

72. Xue Z., Zhang Y., Yu W., Zhang J., Wang J., Wan F., Kim Y., Liu Y., Kou X. (2019): Recent advances in aflatoxin B1 detection based on nanotechnology and nanomaterials-A review. Analytica chimica acta, 1069:1-27. 
73. Yan Z., Chen S., Wang H., Wang B., Wang C., Jiang J. (2008): Cellulose synthesized by Acetobacter xylinum in the presence of multi-walled carbon nanotubes. Carbohydrate Research, 343 (1):73-80.

74. Zhu C., Li F., Zhou X., Lin L., Zhang, T. (2014): Kombucha-synthesized bacterial cellulose: Preparation, characterization, and biocompatibility evaluation. Journal of Biomedical Materials Research Part A, 102 (5):1548-1557.

\section{Tables}

Table (1). Particle size (nm) of AgNPs synthesized under gamma-ray

\begin{tabular}{|ll|}
\hline Nanoparticles & Particle size $(\mathrm{nm})$ of AgNPs \\
\hline $25 \%$ of distribution< & $28.0 \mathrm{~nm}$ \\
\hline $25 \%$ of the distribution & $28.0-49.5 \mathrm{~nm}$ \\
\hline $25 \%$ of the distribution & $49.5-73.0 \mathrm{~nm}$ \\
\hline $5 \%$ of the distribution & $73.0-80.9 \mathrm{~nm}$ \\
\hline $10 \%$ of the distribution & $80.9-106.8 \mathrm{~nm}$ \\
\hline $10 \%$ of the distribution & $106.8-210.9 \mathrm{~nm}$ \\
\hline
\end{tabular}

Table (2): FTIR spectrum of BC and BC/AgNP composite 


\begin{tabular}{|c|c|c|c|}
\hline BC & $\begin{array}{l}\text { BC/AgNPs } \\
\text { composite }\end{array}$ & Functional groups & Reference \\
\hline 3340.3 & 3340.8 & $\mathrm{O}-\mathrm{H}$ out of phase bending & $\begin{array}{l}\text { (Cacicedo et al., } \\
\text { 2020) }\end{array}$ \\
\hline 2976.1 & 2974.9 & \multirow[t]{2}{*}{ Alkane (C-H stretching) } & \multirow{2}{*}{$\begin{array}{l}\text { (Cacicedo et al., } \\
\text { 2020) }\end{array}$} \\
\hline 2892.5 & 2895.5 & & \\
\hline 1640.2 & 1644.2 & Carbonyl $(C=0)$ & $\begin{array}{l}\text { (Wang et al., } \\
\text { 2017) }\end{array}$ \\
\hline 1426.3 & 1426.7 & $\mathrm{CH}_{2}$ & (Zhu et al., 2014) \\
\hline 1369.6 & 1367.5 & $\mathrm{C}-\mathrm{H}$ & $\begin{array}{l}\text { (Cacicedo et al., } \\
\text { 2020) }\end{array}$ \\
\hline 1321.9 & 1322 & $\mathrm{O}-\mathrm{H}$ in plane & $\begin{array}{l}\text { (Osorio et al., } \\
\text { 2019) }\end{array}$ \\
\hline 1158.3 & 1157.2 & $\mathrm{C}-\mathrm{O}-\mathrm{C}$ & (Cui et al., 2014) \\
\hline 1022.3 & 1048 & $\mathrm{C}-\mathrm{O}-\mathrm{C}$ and $\mathrm{C}-\mathrm{O}-\mathrm{H}$ & $\begin{array}{l}\text { (Huang et al., } \\
\text { 2015) }\end{array}$ \\
\hline -- & 1545.5 & $\begin{array}{l}\text { resulting from the hydrogen bonding interaction between } \\
\mathrm{BC} \text { and AgNPs }\end{array}$ & $\begin{array}{l}\text { (Wan et al., } \\
\text { 2020). }\end{array}$ \\
\hline
\end{tabular}

Table (3). Physical Parameters obtained from the XRD

\begin{tabular}{|llllll|}
\hline Samples & $\boldsymbol{\beta}$ & $\mathrm{I} / \mathrm{l1}$ & 2Theta $(\mathrm{deg})$ & $\boldsymbol{\theta}(\mathrm{rad})$ & ACS(nm) \\
\hline BC & 1.7217 & 100 & 22.57 & 0.1963 & 5.416 \\
\hline BC/AgNPs composite & 1.4253 & 100 & 22.86 & 0.1993 & 5.409 \\
\hline
\end{tabular}

Table (4): Antibacterial effect of BC/ AgNP composite, pure BC, AMC, CAZ, and S against tested bacteria 


\begin{tabular}{|c|c|c|c|c|c|}
\hline \multirow[t]{2}{*}{ Bacterial strain } & \multicolumn{5}{|c|}{ Zone inhibition (mm) } \\
\hline & $\mathrm{BC} / \mathrm{Ag}$ composite & $\mathrm{BC}$ & AMC & CAZ & $S$ \\
\hline Enterococcus faecalis & $9 \pm 0.57$ & 0.0 & 0.0 & $7 \pm 0.57$ & $14 \pm 1.5$ \\
\hline Staphylococcus aureus & $9 \pm 1$ & 0.0 & 0.0 & $6 \pm 0.57$ & $13 \pm 0.28$ \\
\hline Listeria monocytogenes & $10 \pm 1.15$ & 0.0 & 0.0 & 0 & $20 \pm 1.7$ \\
\hline Proteus mirabilis & $8 \pm 0.5$ & 0.0 & 0.0 & 0 & $28 \pm 1$ \\
\hline Escherichia coli & $7 \pm 0.28$ & 0.0 & 0.0 & 0 & $19 \pm 0.57$ \\
\hline
\end{tabular}

$\mathrm{BC}=$ Bacterial Cellulose, $\mathrm{AMC}=$ amoxicillin/clavulanic acid, $\mathrm{CAZ}=$ ceftazidime,

$S=$ streptomycin

\section{Figures}

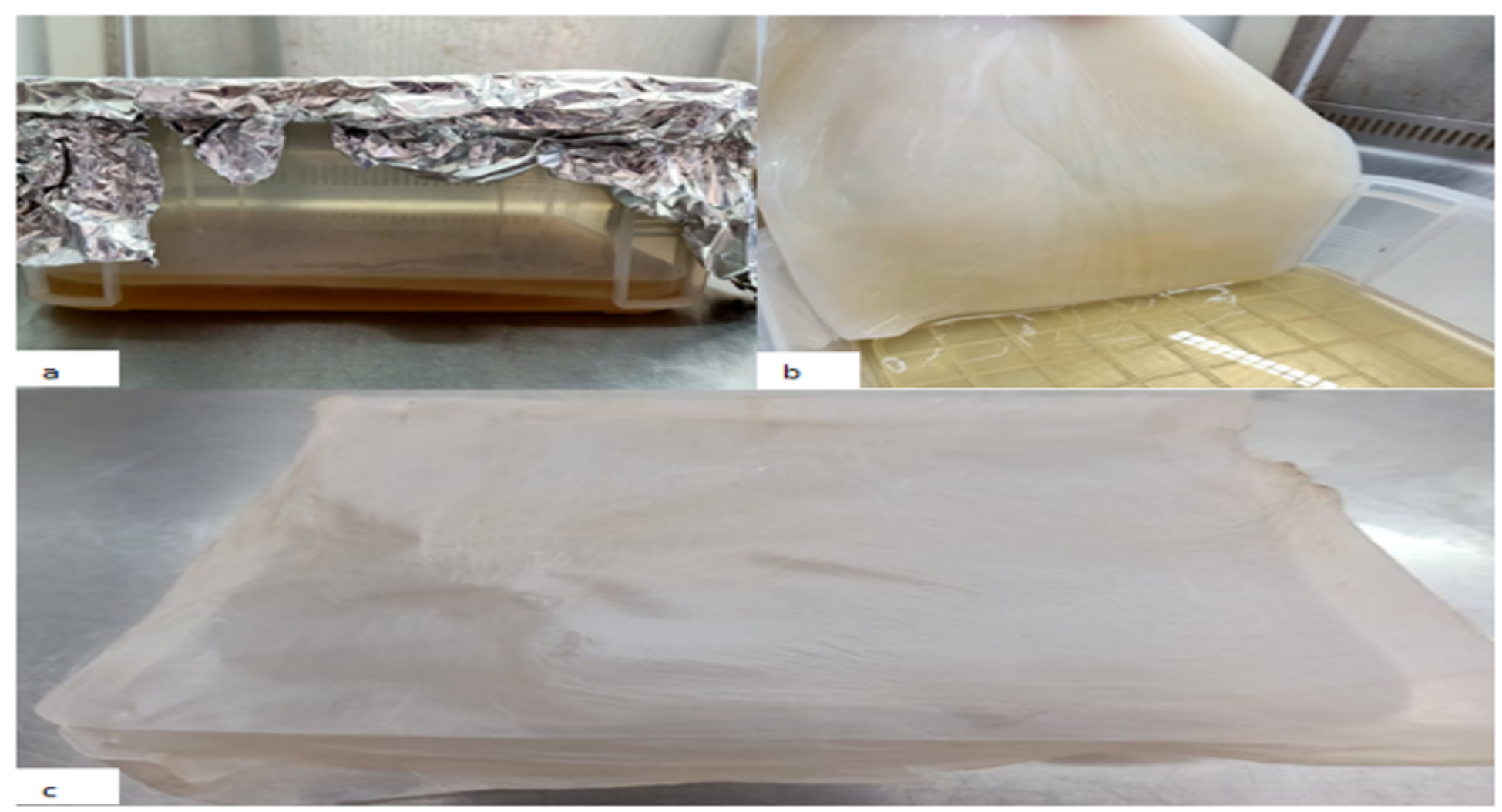

Figure 1

BC produced by Komagataeibacter rhaeticus N1 MW322708 strain on modified HS medium at 30oC for 10 days using static culture conditions (a), harvesting of $B C(b)$ and $B C$ after purification and drying (c) 


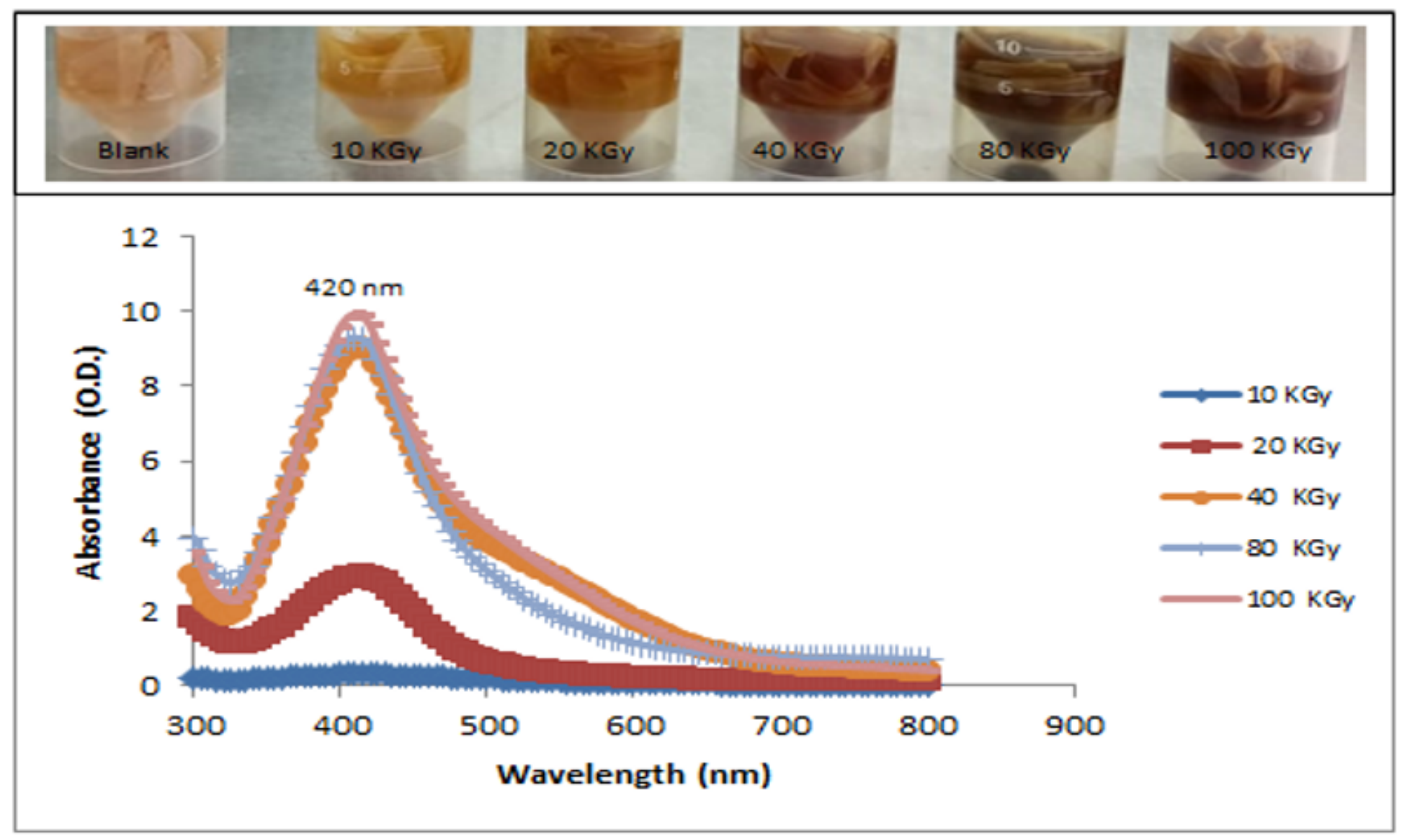

Figure 2

UV-visible spectrum of silver nanoparticles synthesized by BC under different doses of gamma-ray.
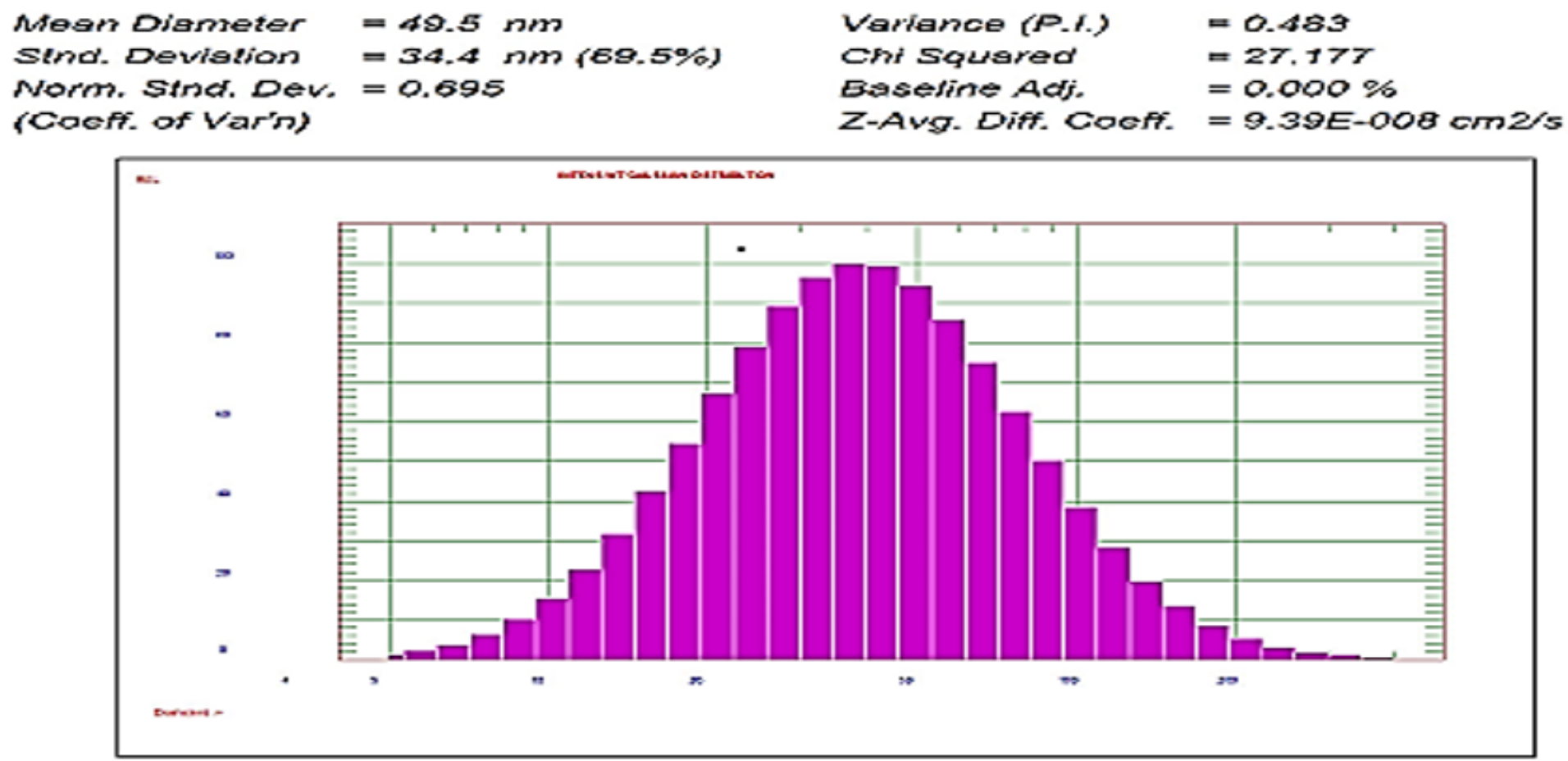

Figure 3 
DLS analysis of colloidal AgNPs synthesized under gamma-ray

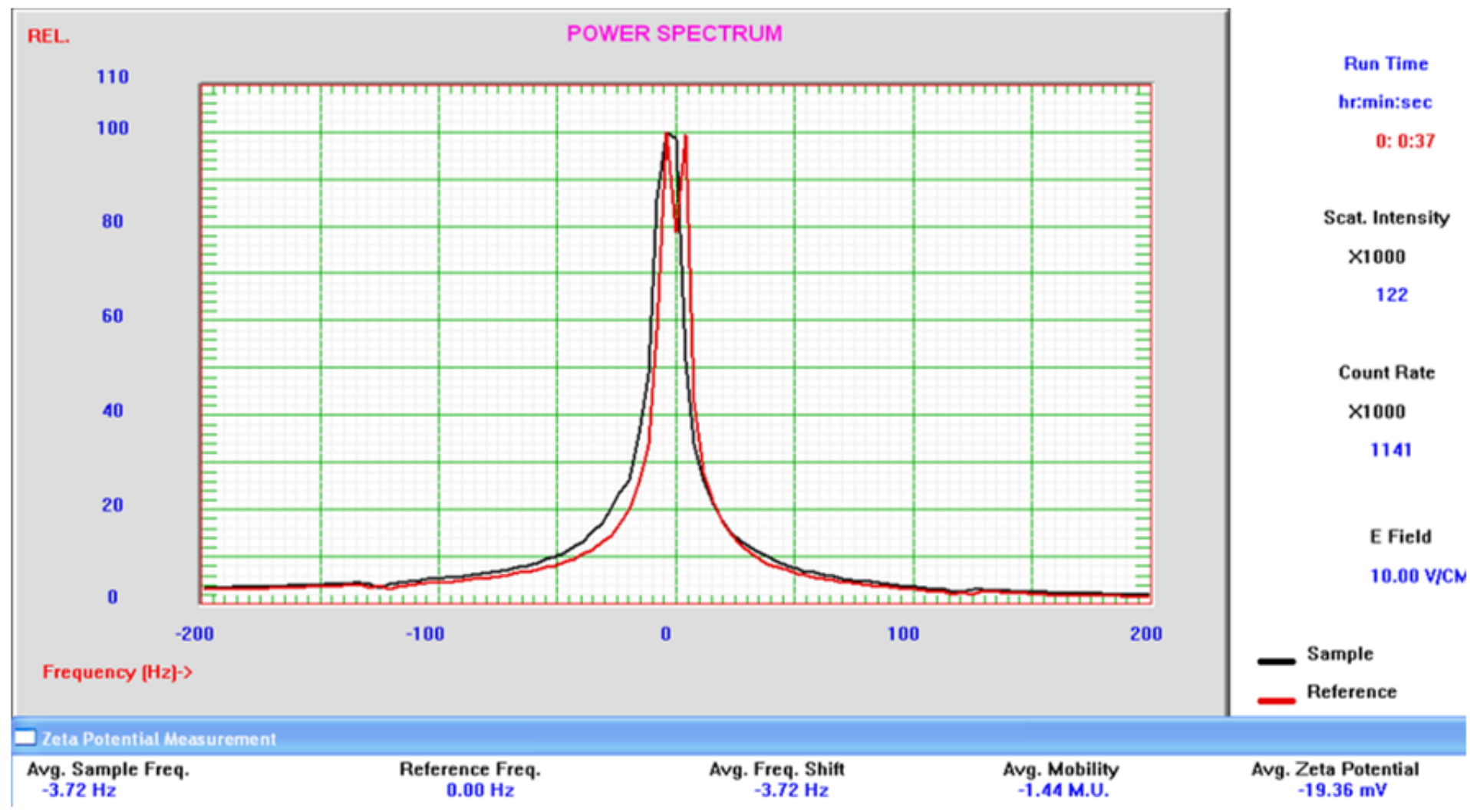

\section{Figure 4}

zeta potential of colloidal AgNP synthesized under gamma irradiation 


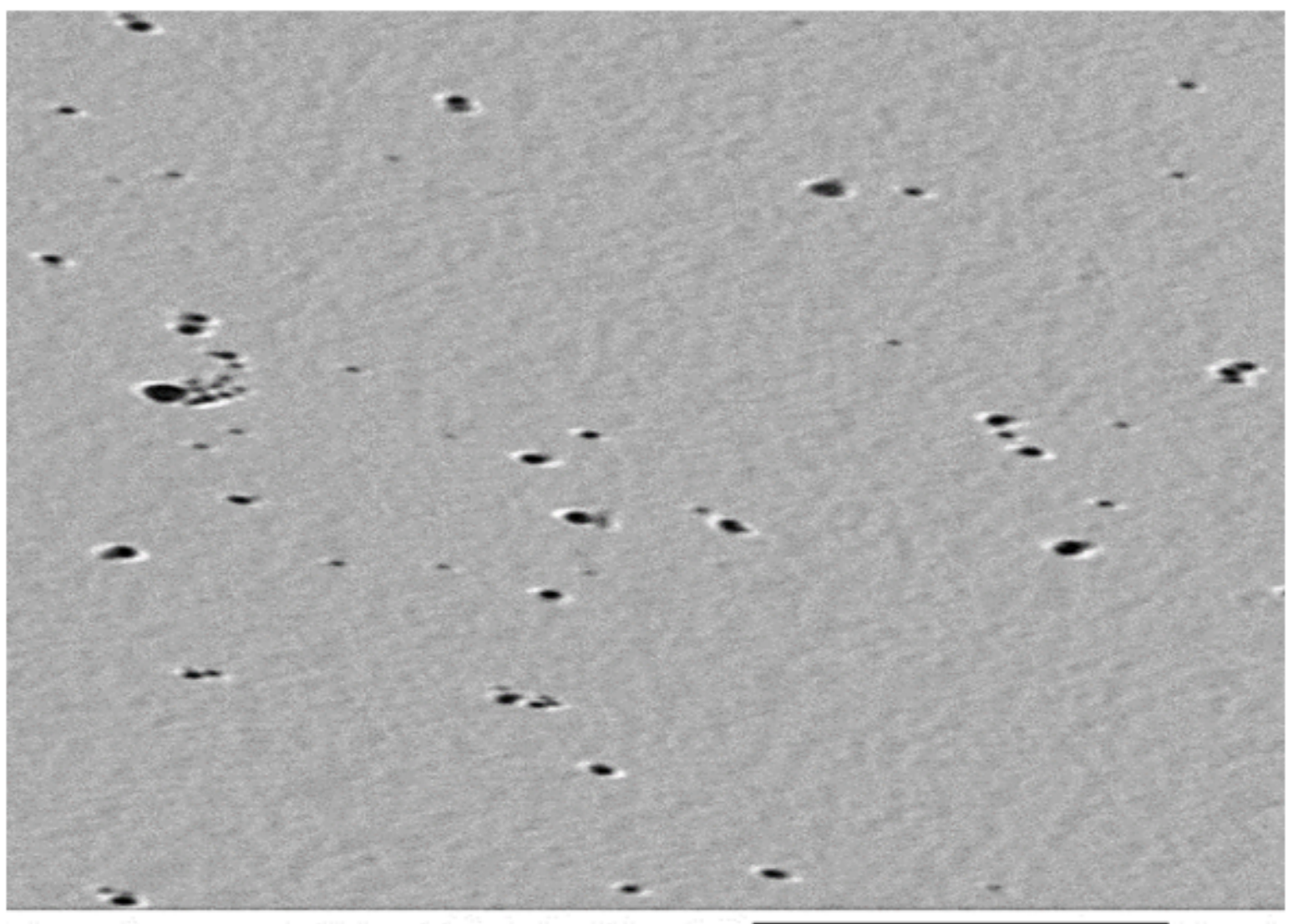

$500 \mathrm{~nm}$ I TV $=80.0 \mathrm{kV}$

Dix $x \in$ L Mey $=20000 x$

तMT CAmคr

Figure 5

TEM micrographs and particles size of synthesized AgNP 

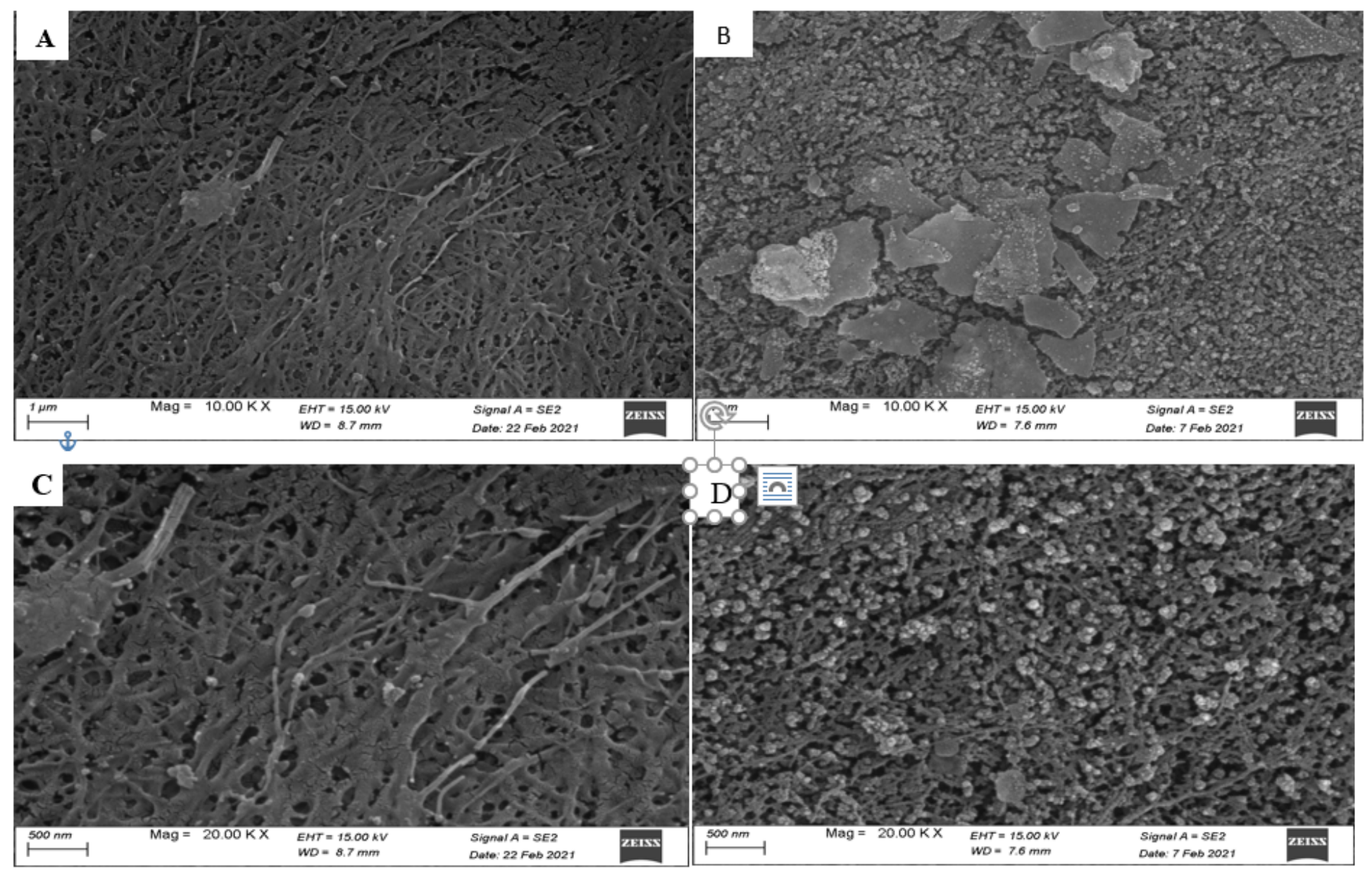

\section{Figure 6}

FESEM images (A, C) purified BC showing 3D network of fibers, $(B, D) B C$ /AgNP composite that shows impregnated AgNP (white dots) into BC nanofibers 

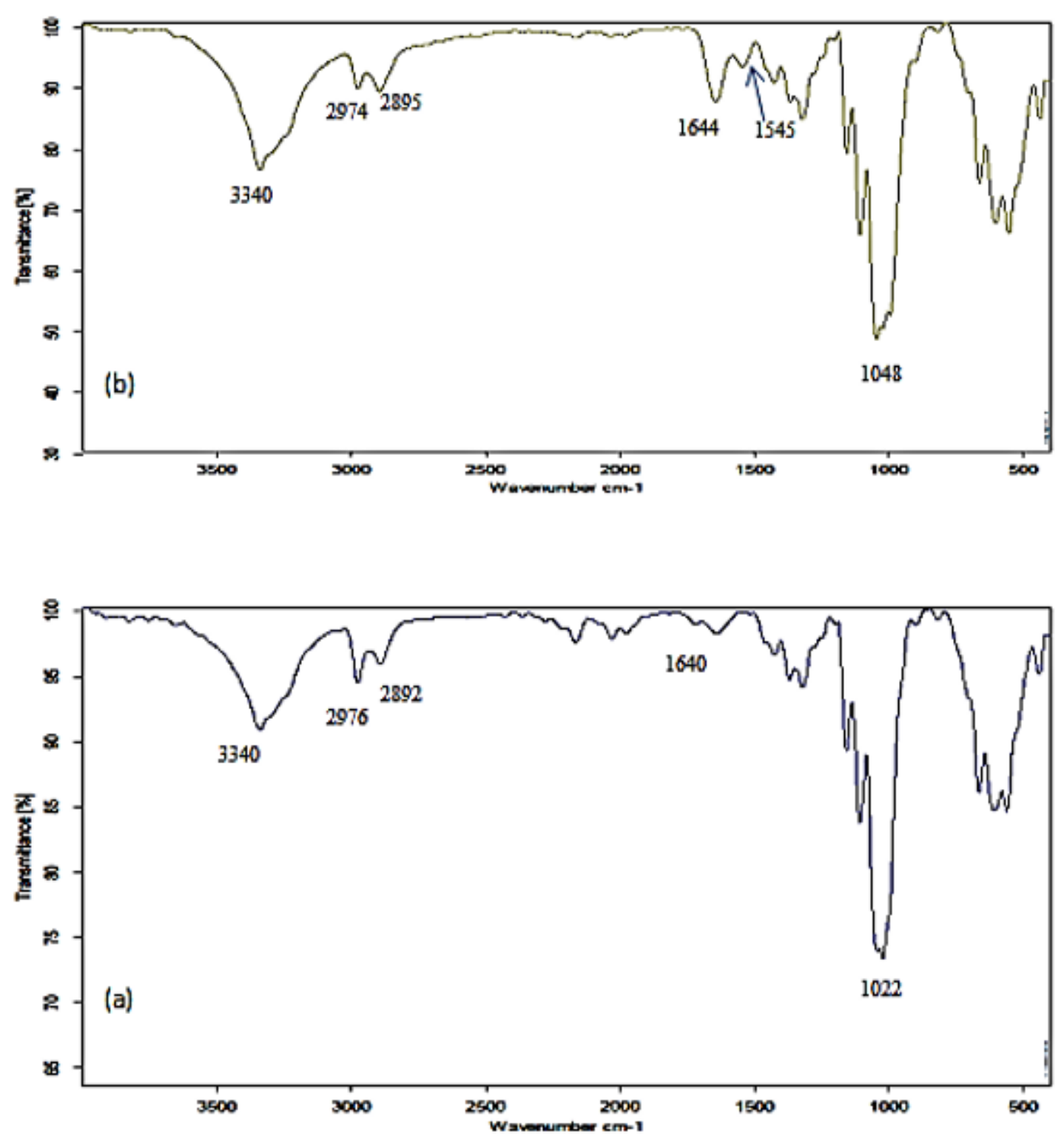

Figure 7

FTIR diagram (a) BC, (b) BC/AgNP composite 


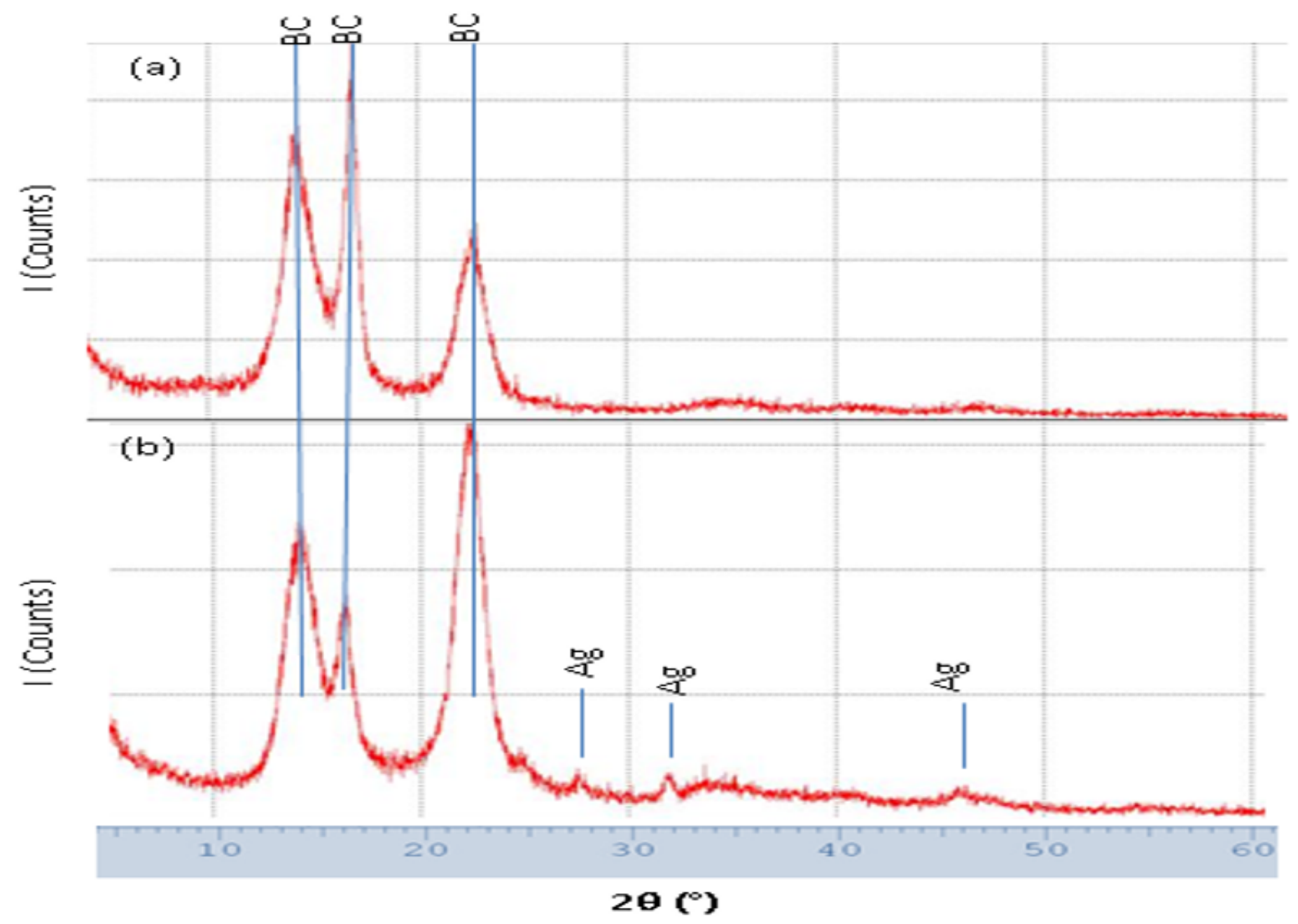

Figure 8

X-ray diffraction (XRD) patterns of purified BC (a) and BC/ AgNP composite (b) 